\title{
ROMOWIE - WSZĘDZIE OBCY. PRZYKŁAD FRANCJI I INNYCH KRAJÓW EUROPEJSKICH
}

\author{
ROMA - OTHERS EVERYWHERE. \\ AN EXAMPLE OF FRANCE \\ AND OTHER EUROPEAN COUNTRIES
}

\begin{abstract}
Why Europe treats Roma as "others" and why Europe is "foreign" to Roma? The starting point is the relationship of domination of one collective entity - European countries which are affiliated to the EU on the other countries (groups having the status of minorities, the most marginalized and discriminated). This dependence describes the category of foreign, developed by Marc Augé as a concept "close-another". Following this concept, the authors of the article distinguish four criteria of analysis: endoetnonim, language, habits (routine practices) and a place for life, which show the mechanism of differentiation and domination, present in most collective entities. The proposed approach has been applied to some European countries, in particular to France, which policy of domination I discrimination against Roma provides many wondering examples, which are still worth a fundamental rethinking of the theoretical plane.
\end{abstract}

Key words: Roma; France; Europe; discriminatory policy; cultural domination; the issue of Roma in politics
ADAM POMIECIŃSKI

Uniwersytet im. Adama Mickiewicza, Poznań E-mail: adpom@amu.edu.pl

AGNIESZKA CHWIEDIUK

Uniwersytet im. Adama Mickiewicza, Poznań

E-mail: agach@amu.edu.pl

CITATION: Pomieciński, A., \& Chwiediuk, A. (2017).

Romowie - wszędzie obcy.

Przykład Francji I innych krajów europejskich. Sprawy Narodowościowe. Seria nowa, 2017(49). https://doi.org/10.11649/sn.1279

This work was supported by the authors' own resources.

No competing interests have been declared. Both authors participated in elaborating research ideas and writing the manuscript.

This is an Open Access article distributed under the terms of the Creative Commons Attribution 3.0 PL License (creativecommons.org/licenses/by/3.0/pl/), which permits redistribution, commercial and non-commercial, provided that the article is properly cited. (C) The Author(s) 2017.

Publisher: Institute of Slavic Studies, Polish Academy of Sciences 
Dlaczego Europa traktuje Romów jak „obcych" i dlaczego Romom „obca” jest Europa? Punktem wyjścia jest relacja dominacji jednego podmiotu zbiorowego, jakim są państwa europejskie zrzeszone w UE, nad drugim, czyli grupami mającymi status mniejszości, najczęściej zmarginalizowanej oraz dyskryminowanej. Tę zależność opisuje kategoria obcego, rozwinięta przez Marca Augé jako koncepcja "bliskiego-innego". W nawiązaniu do niej autorzy artykułu wyodrębniają cztery kryteria analizy: endoetnonim, język, zwyczaje (praktyki rutynowe) oraz miejsce do życia, które ukazują mechanizm różnicowania oraz dominowania, obecny u większości podmiotów zbiorowych. Zaproponowane podejście zostało odniesione do krajów europejskich, w szczególności do Francji, której polityka dominacji/dyskryminacji wobec Romów dostarcza wielu zastanawiających przykładów wartych nadal dogłębnego przemyślenia teoretycznego.

Słowa kluczowe: Romowie; Francja; Europa; polityka dyskryminacyjna; dominacja kulturowa; kwestia romska w polityce

K iedy w 1831 roku postać pięknej, lecz biednej Cyganki Esmeraldy przemówiła z kart powieści Notre Dame de Paris autorstwa Victora Hugo, w Europie Cyganie stanowili już trwały element społeczeństw, podobnie we Francji, która po ponad 9 wiekach budowania swej odrębności wkroczyła w okres rządów Ludwika Filipa. Sprzyjały one społecznym antagonizmom, ale zwiastowały także wielką erę industrialną. Z jednej strony rosła bowiem pozycja zamożnej burżuazji i właścicieli ziemskich, z drugiej dalszej pauperyzacji uległy warstwy niższe. Victor Hugo, czyniąc z Cyganki jedną z pierwszoplanowych postaci romansu, nie tylko wyraził swą sympatię do plebsu. Sygnalizował też obecność w nim grupy, która zamieszkiwała Francję od początków XV wieku (pierwsze wzmianki o niej pochodzą z 1419 r.), ale już wtedy zaliczano ją pogardliwie do „nomadów”, prześladowanych regularnie od czasów Ludwika XIV.

Tragiczne losy młodej Cyganki spalonej na stosie, w której zakochuje się i wyrzutek Quasimodo, i reprezentant warstwy cieszącej się uznaniem we Francji, archidiakon Klaudiusz Frollo, to niemalże parabola społeczeństwa francuskiego. Jest ono silnie rozwarstwione, ale piętnuje przy tym Inność, czyniąc z niej Obcość „nie do przyjęcia”. Sytuuje na marginesie fizyczną ułomność, którą obrazuje garbus Quasimodo żyjący w mrokach katedry, ale i egzotyczne piękno połączone z niekonwencjonalnym zachowaniem będące udziałem Esmeraldy. Odrzucanie skrajności możliwe jest dzięki uprzywilejowaniu większości, którą uosabia Frollo. Pozostawiając w tle perypetie fikcyjnych bohaterów, warto zauważyć fakt, że ich losy sygnalizują podobieństwa do zachowań realnych, które decydują o tym, jak grupy rozpoznają się jako swoje i obce. Nawiązując do tej zasady, w artykule chcielibyśmy w jakiejś mierze odpowiedzieć na następujące pytanie: dlaczego Europa traktuje Romów jak „obcych” i dlaczego Romom „obca” jest Europa? Szczególnym przykładem będzie dla nas Francja. To właśnie do tego kraju po wejściu do Unii Europejskiej Rumunii i Bułgarii ludność pochodzenia romskiego zaczęła masowo migrować w poszukiwaniu lepszych warunków do życia. Szybko jednak ich los okazał się dużo gorszy niż innych migrantów przybywających do Francji. Bardzo restrykcyjna polityka rządów francuskich, wzmacniająca negatywne stereotypy funkcjonujące już od wieków na temat Les Tsiganes, pokazała jedynie rozdźwięk pomiędzy „obcością" a pochwałą „różnorodności”. Jednocześnie nie traktujemy przykładu francuskiego jako odosobnionego, lecz staramy się poszukiwać analogii w innych społeczeństwach europejskich, pokazując „problem romski" w szerszym kontekście polityczno-kulturowym. 
Rozliczne publikacje naukowe poświęcone Romom we Francji i w Europie, chociaż dostarczają szczegółowych analiz wskazujących na zmarginalizowanie tej społeczności, unikają jednak formułowania rozstrzygających teorii tłumaczącej przyczyny tej sytuacji. Zastanawia ta ostrożność, zwłaszcza że istnieją liczne propozycje usiłujące zrozumieć zachowania z jednej strony powodujące tak zwane napięcia, z drugiej usiłujące im zapobiegać. W narracjach badaczy odnaleźć można zatem konstatacje na temat wciąż utrzymujących się negatywnych stereotypów zakorzenionych w dyskursach społeczeństw przyjmujących, praktykowania krypto-rasizmu w politykach lokalnych i państwowych, mechanizmów neoliberalnych pogłębiających pauperyzację oraz hermetyczność grup romskich. W efekcie otrzymujemy wyartykułowany i poparty egzemplifikacjami zbiór potencjalnych czynników generujących „konflikt” stron. W odpowiedzi na wyżej sformułowane pytanie można zaryzykować zatem następujące stwierdzenie. Współczesne ujęcia sytuacji Romów wskazują na relacje dominacji jednego podmiotu zbiorowego, jakim są państwa europejskie zrzeszone w Unii Europejskiej, nad drugim, czyli grupami mającymi status mniejszości w sytuacji marginalizacji. Sytuację tę opisuje kategoria obcego, do której jeszcze nawiążemy.

Rozwinięcie tej myśli wymaga szeroko zakrojonej analizy, popartej krytycznym przeglądem stanu badań nad Romami we Francji i w innych krajach Europy od początków XX wieku. Z uwagi jednak na ograniczenia narzucone zarówno przez sam przedmiot refleksji, jak i objętość tego tekstu, potraktujemy naszą interpretację jako szkic do obszerniejszej pracy. Ograniczymy się zatem do prezentacji czterech ważnych aspektów warunkujących rozważania nad relacją dominacji ze szczególnym uwzględnieniem pierwszego i częściowo drugiego oraz do kilku niezbędnych egzemplifikacji.

(1) Po pierwsze, tak zwana sytuacja Romów we Francji i innych krajach europejskich zakłada długofalową interakcję podmiotów zbiorowych, które na przestrzeni wieków wypracowały zupełnie odmienne sposoby funkcjonowania w świecie. Poza zgodą na nieuchronne uproszczenia wynikające z zabiegu generalizacji, podstawową trudnością, jest definicja owych podmiotów, z którą wiązać się będą także określone kryteria pozwalające wskazać cechy różniące obie strony. W tym celu przyjmiemy najprostsze rozwiązanie, odwołując się do obszarów różnicujących większość podmiotów zbiorowych takich, jak: endoetnonim, język, zwyczaje („zasady życia”) oraz miejsce do życia (praktyki rutynowe).

(2) Po drugie, trudno nie założyć, że badacze nie są świadomi tego „prostego" faktu, jakim jest relacja dominacji. Jednak czymś zupełnie innym jest założenie o jej istnieniu, a czym innym jej denuncjacja w postaci zwartej propozycji programu "naprawczego", popartego ich naukowym autorytetem. Musiałby on zmierzać w jakieś mierze do osłabienia silnej pozycji kulturowej państw, które obecnie nieustannie ją wzmacniają, dyktując funkcjonowanie strukturom unijnym. Ani byle imperia kolonialne - Francja z historycznie ugruntowaną misją cywilizacyjną i Wielka Brytania z hegemonią języka angielskiego - ani Niemcy od wieków decydujący o relacjach Europy z Rosją, jako czołowe państwa nie są gotowe do rezygnacji z tej przywódczej roli, którą legitymizuje stanowienie standardów etycznych wobec mniejszości i w wypracowywaniu wspólnych wartości „europejskich", czego wymagałaby być może sytuacja. Gwarancje dla praw mniejszości i hasło „tolerancja”, w praktyce stanowią przecież narzędzia dyscyplinujące relacje, które przebiegają w granicach silniejszych politycznie podmiotów. Budują one swoją pozycję "silniejszego" między innymi poprzez stopniową internalizację „innych” (np. Dainotto, 2007), w celu podtrzymania własnej tożsamości. Jest to uogólnienie, zgodne z propozycjami antropologicznymi, które definiują interakcje w społeczeństwach złożonych w kategoriach władzy, dominacji i rywalizacji, ale także wspólnych tradycji (np. Abélès, 2004, ss. 1-26; 
Hann, 2012, ss. 1119-1128). Ta ostatnia perspektywa wydaje się istotna dla funkcjonowania Unii Europejskiej, która nie może istnieć jako „wspólnota różnorodności” wyłącznie w oparciu o jednakową walutę oraz rynek i uznanie dla inności, w którą wpisują się Romowie z trudem osiągający jednomyślność w zakresie współtworzenia ideologicznej propozycji, jaką jest europejski projekt „dziedzictwa kulturowego i narodowego".

(3) Po trzecie, za przydatny należałoby uznać paradygmat konstruktywistyczny. Dostrzegając zalety tego podejścia - na przykład możliwość wykazania dynamiki zjawisk - pewną trudnością pozostaje wyjście obserwatorów poza postrzeganie zjawisk (relacji) w perspektywie "tu i teraz". Tymczasem wskazanie na relację dominacji wobec takich podmiotów jak Romowie (zasadniczo grupy mniejszościowe), wymaga uwzględnienia także wzorców długiego trwania. Dla antropologa oznacza to dokonanie ponownie pewnej generalizacji na podstawie źródeł zastanych, bez możliwości odwołania się do „własnej” empirii.

(4) Po czwarte, kreacja tekstu naukowego, zwłaszcza w przypadku grup o słabszej pozycji politycznej, jest aktem etycznym, wprowadzającym dany podmiot do sfery publicznej na zasadach, które nie są wcześniej przez niego w pełni wynegocjowane. Przyzwolenie grupy na opublikowanie informacji na jej temat nie wyczerpuje przecież problemu, jakim są skutki interpretacji i oddziaływania tekstów udostępnianych nawet w relatywnie zamkniętym obiegu informacji, jak to ma miejsce właśnie w przypadku dyskursu akademickiego. W takich okolicznościach trudno uniknąć „efektu ideologizacji”. Tak roboczo określimy tu postmodernistyczną spuściznę, z którą należy się zmierzyć, w pewnym sensie przyjmując rolę porte parole podmiotu zdominowanego.

Mając na względzie powyższe warunki, przytoczone tu w wielkim skrócie, chcielibyśmy poprzestać, jak już wspomnieliśmy, na rozwinięciu (częściowym) pierwszego z nich, przy odwołaniu się do drugiego, zwłaszcza do koncepcji „bliskiego-obcego" (np. Pacquot \& Augé, 2006, s. 10). „Bliscy-inni” to tacy ludzie, którzy są pozornie z nami zintegrowani, ale w praktyce są odrzuceni, stygmatyzowani, zniewoleni. Żyją nie tyle z nami, ile obok nas. Sytuacja dominacji skutkująca marginalizacją jednego z podmiotów wiąże się z jednoczesnym utrzymywaniem odrębności zarówno przez niego, jak i przez stronę silniejszą. Romowie, wpisując się $w$ ten mechanizm, pozostają jednocześnie wciąż $w$ roli wspomnianego "bliskiego-obcego", co sprzyja ich marginalizacji.

Wobec tego relacja Romów z państwami Unii Europejskiej, w tym z Francją, kształtuje się z uwagi na nierówne pozycje polityczne. Towarzyszy temu celowo utrzymywana odrębność obu stron, przy czym w przypadku państw, proces ten wzmacnia ich silną pozycję polityczną, stwarzając pole do ich dominacji. W konsekwencji stawiamy tu pytanie, na ile sama kategoria obcości jest wystarczająca do diagnozy sytuacji, o której mowa. Skłaniamy się do poglądu, że jako taka stanowi ona jedynie kategorię opisu, ale nie wyjaśniania. Wzajemna obcość Romów i społeczności przyjmujących to konsekwencja zasady różnicowania (Ardener, 1992, ss. 21-43), bez której tożsamość współczesnych społeczeństw, ale i Unii Europejskiej nie istniałaby.

\section{DWA PODMIOTY}

Wskazanie na relacje dominacji wymaga najpierw zdefiniowania uwikłanych w nią podmiotów zbiorowych. Pierwszy z nich coraz częściej figuruje w literaturze przedmiotu pod pojęciem „Europy". Metafora ta odnosi się do realiów Starego Kontynentu ujmowanych jako konstrukt polityczny i ekonomiczny (np. Giddens, 2009, 2014; Walters \& Haahr, 2011) 
zmierzających do zjednoczenia w strukturach Unii Europejskiej wielkich organizmów państwowych, w których większość stanowią ugruntowane w długim procesie historycznym społeczeństwa o wykształconej tożsamości narodowej. Określane są one też jako „Europejczycy", jednakże nazwa ta stosowana jest także w stosunku do narodów bez państwa i bywa, że ma silne konotacje ideologiczne (np. Barzini, 2001; Dainotto, 2007).

Drugi z podmiotów tworzą grupy funkcjonujące w rozproszeniu w granicach tych państw, które łączy jednak duże podobieństwo, nie na tyle silne, aby doszło do znaczącej dla nich konsolidacji. Ich obecność w realiach „Europy” odnotowano już pomiędzy VII a X w. n.e. (Gerlich, 2011, s. 159), gdzie przybyły, migrując z Północnych Indii. Tam zawiązały się ich zasady praktykowane do dziś i decydujące o ich odmienności. Przede wszystkim skutkują one predyspozycją do budowania i utrzymywania hermetycznych wspólnot w oparciu o silne prawo zwyczajowe przy jednoczesnym wykorzystaniu okoliczności wynikłych z odmiennych wzorców kulturowo-społecznych narodów, wśród których osiedlity się lub akurat przebywają z racji wędrownego trybu życia. Jako taki, stanowi on także ich charakterystyczny wyróżnik kulturowy. Innym okazuje się utrzymujący się brak jedności politycznej, co przejawia się w nadal silnej tendencji do samookreślania się wspólnot jako odrębnych od innych im podobnych. Oddają to ich nazwy własne, zwykle wyrażające zdecydowany dystans do określeń takich jak Cyganie czy Romowie. W mentalności wielu narodów Europy utrwaliło się bowiem silne przekonanie, że w zasadzie nie ma żadnej różnicy, jak nazwie się tych ludzi, gdyż i tak wiadomo, że chodzi zasadniczo o obcych, dziwnych, których lepiej się „wystrzegać”. Tymczasem od przynajmniej pół wieku reprezentanci Romów i podobnych grup coraz częściej deklarują publicznie, że nie jest im obojętne ani to kim są, ani to, jak się ich określa. Dobrym przykładem świadomości położenia historycznego może być wypowiedź znanego romskiego adwokata i obrońcy praw człowieka lana Hancocka:

Gdyby Polacy, a także inne narodowości, uczyli się o historii Romów w szkole, wiedzieliby, że w przeszłości to surowe prawodawstwo nie pozwoliło Romom osiedlać się czy też kupować w sklepach, tak więc musieli wędrować dalej i szukać jedzenia wszędzie, gdzie mogliby je znaleźć i nakarmić swoje rodziny. To nie-Romowie są za to odpowiedzialni. Ale ponieważ Romowie musieli przeżyć, zostali obwinieni za sytuację, której nie spowodowali (Cudak, 2008, s. 12).

Historia Romów - jedynie zdawkowo przez nas podana - wpłynęła na obecny kształt ich kultury. Wzajemna nieufność pomiędzy Romami a nie-Romami ("Gadzio" - innymi, obcymi, nieczystymi, niezasługującymi na szacunek) kształtowała się przez wieki i spowodowała, że grupy Cyganów nadal żyją "oddzielnie” i "obok” nas. Wydaje się, że jest to modelowy przykład odzwierciedlający "bliskich-innych”, o których pisał Marc Augé. Les autres jawią się jako społeczności niezrozumiałe, a zarazem pozbawione szacunku i akceptacji. Nielubienie ich sięga wieków i jest dobrze ugruntowane. Pomiędzy Romami a "Gadzio" nie wytworzył się żaden trwały system wzajemnego rozumienia. Ciągte napięcia między mechanizmami odrzucenia i obrony pogłębiają tylko różnice i utrwalają negatywne stereotypy, które funkcjonują z powodzeniem po obu stronach.

ROMOWIE WE FRANCJI: "WIDOCZNE” SKUTKI DOMINACJI

W lipcu 2010 roku w pobliżu francuskiego miasteczka Blois położonego w Regionie Centralnym nad Loarą grupa około pięćdziesięciu Romów zaatakowała posterunek żandarme- 
rii. Jak donosiły media, "napastnicy” byli uzbrojeni w metalowe pręty i siekiery, zniszczyli sygnalizację świetlną, spalili trzy samochody, ścięli kilka drzew. Bezpośrednią przyczyną ataków były wcześniejsze wydarzenia związane z zastrzeleniem przez jednego z żandarmów młodego Roma, który nie chciał poddać się kontroli i w efekcie próbował uciekać samochodem przed policjantami. Jego ciało znaleziono porzucone w pobliżu dużego obozowiska Romów pomiędzy Saint Aignan a Blois. Do spacyfikowania romskich zamieszek rzucone zostały oddziały policji francuskiej i wojska (np. „Francja: Atak Romów na posterunek żandarmerii", 2010).

Do innych, równie tragicznych zdarzeń, doszło kilka lat później. W sierpniu 2015 roku media informowały o zorganizowanej przez grupę kilkudziesięciu Romów blokadzie autostrady A1 we Francji, jednej z najbardziej uczęszczanych dróg Europy. Autostrada ta w pobliżu miejscowości Roye w Pikardii stała się kompletnie nieprzejezdna. Romscy demonstranci nie przebierali w środkach: płonęły drewniane palety i opony. Przez długi czas żandarmi byli bezsilni w obliczu zajść na A1. Protest około sześćdziesięciu Romów był związany z wcześniejszą strzelaniną w obozowisku w Roye. Według relacji świadków pijany mężczyzna z niewiadomych przyczyn wtargnął do obozowiska Romów, wyciągnął broń i zaczął strzelać. W tych nieszczęśliwych zajściach zginęły cztery osoby, wśród nich sześciomiesięczne niemowlę, kobieta i interweniujący policjant. Na ruchliwej A1 Romowie domagali się, aby syn jednej z ofiar strzelaniny, który przebywał w areszcie w Amiens, mógł pod eskortą policji uczestniczyć w pogrzebie swojego ojca (np. „Francja: Romowie protestują, zablokowali autostradę A1", 2015).

Te wydarzenia przez długi czas nie schodzity z czołówek newsów prezentowanych w popularnych stacjach telewizyjnych, gazetach i portalach internetowych. Szeroko komentowane były nie tylko w kraju nad Sekwaną, ale i w całej Europie. Niestety nie były one jedynymi, które dotyczyły społeczności romskich traktowanych w kategoriach niechcianych imigrantów. Do podobnych zajść dochodziło w okolicach Paryża, Marsylii, Lyonu, Nantes. „Problem romski” stał się szczególnie istotny dla Francji i Europy po wejściu Rumunii i Bułgarii do Unii Europejskiej w 2007 roku.

To właśnie w tych dwóch krajach zlokalizowane były najliczniejsze skupiska tej ludności na Starym Kontynencie. Po upadku reżimów komunistycznych w Europie Wschodniej Romowie utracili swoje źródła utrzymania: duże zakłady pracy upadały, a państwowe gospodarstwa rolne zostały zamknięte. Pierwszymi bezrobotnymi stawali się często Romowie. Okres przystąpienia nowych krajów do Unii Europejskiej sprawił, że "kwestia romska" nabrała nowego kształtu.

Romowie już jako obywatele Unii Europejskiej zaczęli masowo pojawiać się w krajach Europy Zachodniej. Teoretycznie stali się pełnoprawnymi obywatelami jednoczącej się Europy. W praktyce jednak ich los okazał się dużo gorszy od pozostałych kategorii imigrantów szukających dla siebie godniejszych warunków do życia. Dziesiątki tysięcy Romów w poszukiwaniu lepszego życia znalazło się we Francji. Uboga ludność romska, pozbawiona środków ekonomicznych oraz - jak sami przyznają - lokująca się "na samym dole drabiny społecznej" (Chojnacki, 2008, s. 3), zaczęła tworzyć getta, czyli nielegalne osiedla zlokalizowane najczęściej w pobliżu miast. Tym samym „problem romski” stał się na tyle widoczny, że szybko urósł do poważnego „problemu politycznego”.

Już w trakcie swojej kampanii prezydenckiej Nicolas Sarkozy mówit, że we Francji jest zbyt wielu cudzoziemców, a tożsamość Francuzów jest zagrożona. Jak przekonywat, należy wszelkimi sposobami uchronić Francję przed napływem imigrantów, którzy chcą żyć na koszt państwa. Słowa te wymierzone były głównie w Romów rumuńskich 
i bułgarskich. Po objęciu rządów przez Sarkozy'ego deportacje ludności romskiej stały się istotnym narzędziem gry politycznej, zaś wykluczenie Romów ze społeczeństwa francuskiego przybrało bardzo brutalne formy. Górę wzięły stereotypowe wyobrażenia Romów postrzeganych jako przestępców, żebraków, bezrobotnych, brudnych, niewykształconych, degeneratów i wykolejeńców. Likwidacje obozów Romów i ich późniejsze deportacje samolotami do Rumunii oraz Bułgarii uzyskały teoretyczne alibi dla poczynań nowych władz w kwestii rozwiązania „problemu społecznego" ludności romskiej we Francji. Odwieczny stereotyp „,bezproduktywnych Cyganów” zyskał nową odsłonę jako współczesnych nomadów niezdolnych do integracji w nowoczesnym społeczeństwie.

Warto w tym miejscu jeszcze raz odwołać się do historii narodu romskiego. Od czasu kiedy Romowie opuścili Indie, ich życie było zawsze w ruchu. Kiedy dotarli do Europy, szybko spotkali się z restrykcyjnym prawem, które mocno ograniczało ich osiedlanie się, zatrudnianie czy edukację. Wędrowny i koczowniczy tryb życia nie pasował do kulturowych modeli osiadłych społeczeństw Starego Kontynentu. Cyganie postrzegani byli jako "ludzie luźni” i „nieproduktywni włóczędzy” (Mirga \& Gheorghe, 1997, s. 17). Nieustannie zmuszano ich do migracji lub ucieczki. W wielu krajach europejskich przez całe wieki traktowano ich jako niewolników. Między innymi strach przed zniewoleniem powodował, a zarazem wymuszał kolejne wędrówki tej grupy etnicznej. Z czasem mechanizmy „obrony" przed Romami nabierały jeszcze ostrzejszego charakteru. Rozdział masowych eksterminacji otwarty został już w latach 20. XVIII wieku. Cesarz Karol VI swoim edyktem nakazał eksterminację wszystkich Romów znajdujących się na terenie państwa Habsburgów, natomiast Otto von Bismarck ustanowił całkowity zakaz przemieszczania się wędrownych grup Cyganów. Chociaż eksterminacja Romów dopełniła się w czasach nazistowskich Niemiec (por. m.in. Radu, 2011, ss. 1-2), to jednak złowieszczy model „radykalnych rozwiązań" nadal utrzymuje się w dyskursie politycznym. Za Elliotem Aronsonem można przyjąć, że mniejszość romska obarczona jest syndromem „kozła ofiarnego" i "agresją przemieszczoną" (Aronson, 2012, s. 320), która wymierzona jest w grupy względnie bezsilne i od początku nielubiane.

Przestrogą dla elit rządzących państwami europejskimi winna być postawa pewnego francuskiego deputowanego. Gilles Bourdouleix, członek parlamentu i burmistrz miasta Cholet koło Nantes, w lipcu 2013 roku odwiedził działkę należącą do miasta, na której swój obóz nielegalnie rozbili Cyganie. Jego prośby o opuszczenie terenu nie zostały przez nich spełnione. Niektórzy z Romów wykonywali obraźliwe gesty w jego stronę, przypominające hitlerowskie salutowanie. W odpowiedzi na to Bourdouleix powiedziat: "Być może Hitler nie zabit ich wystarczająco dużo" (Corbet, 2013). Ministerstwo Spraw Wewnętrznych Francji zwróciło się do prokuratury o zbadanie, czy francuski polityk może być pozwany do odpowiedzialności za usprawiedliwianie zbrodni przeciw ludzkości. Paradoksem całej sytuacji było to, że jeden z nazistowskich obozów zagłady Romów w czasach II wojny światowej znajdował się w Montreuil-Bellay, zaledwie sześćdziesiąt kilometrów od Cholet.

We współczesnej Francji polityczny głos Romów jest mało słyszalny. Niektórzy twierdzą wprost, że Romom w obliczu niedostatku, braku bezpieczeństwa i wykluczenia został on świadomie odebrany (Radu, 2011, s. 2). We Francji, ale jak chcemy dowieść nieco później także w innych krajach Europy, państwa nie są w stanie zapanować nad kryminalizacją romskich slamsów i uporczywym doświadczaniem skrajnej biedy. W efekcie prawa najuboższej grupy etnicznej, która żyje w Unii Europejskiej są ignorowane i tamane. W najlepszym razie nowoczesne instytucje państwowe i ponadnarodowe agendy unijne odwracają się do Romów plecami, a ich polityczne wsparcie ma znikomy wpływ na po- 
prawę codziennego życia. Najprostszym politycznym rozwiązaniem dla władz francuskich miały być deportacje ludności romskiej do krajów ich pochodzenia.

Smutny los Romów obnaża rozdźwięk pomiędzy głoszoną pochwałą różnorodności a odrzucaniem odmienności, które coraz gwałtowniej zachodzą we francuskim społeczeństwie. Szacuje się, że Francja w latach 2008-2009 deportowała od 10000 do 12000 Romów pochodzenia rumuńskiego i bułgarskiego. Paradoksalnie jednak liczba Romów we Francji nie zmniejsza się. Większość z nich ponownie przyjeżdża w te same miejsca. Motywy migracji są ciągle te same: trudne warunki ekonomiczne, ucieczka przed dyskryminacją etniczną i poszukiwanie lepszych warunków do egzystencji. W przypadku Romów należy więc mówić o pewnym cyklu: migracja - deportacja - powrót (Palmer, 2011, s. 48). To pokazuje nieskuteczność francuskiej polityki deportacyjnej.

Obok tego zjawiska mamy do czynienia także z przejawami "selektywnej migracji”, czyli przyjmowania wysoko wykwalifikowanych migrantów, którzy mają pozytywnie wpływać na ekonomię i gospodarkę kraju, przy jednoczesnym odrzucaniu tych wszystkich, którzy mogą stanowić obciążenie dla systemu socjalnego. Romowie nie są więc w stanie uzyskać dostępu do francuskiego społeczeństwa. Deportacje Romów jako rzekomych przestępców i „urodzonych kryminalistów” są zatem czymś więcej niż „zwykłymi” wysiedleniami. Pokazują całkowite wykluczenie Romów z obiegu neoliberalnej ekonomii, edukacji, zatrudnienia, ochrony zdrowia i zakwaterowania.

European Union Agency for Fundamental Rights opublikowała niedawno wyniki badań przeprowadzonych w jedenastu krajach Unii Europejskiej na temat sytuacji Romów. Wyłania się z nich ponury obraz ich społecznego położenia: średnio około 90\% Romów mieszka w gospodarstwach domowych, których zrównoważony dochód jest poniżej krajowej granicy ubóstwa, około 40\% Romów żyje w gospodarstwach domowych, w których w ciągu ostatniego miesiąca jeden z domowników przynajmniej raz musiał pójść spać głodny, gdyż nie wystarczyło pieniędzy na zakup żywności, połowa Romów w ciągu ostatnich dwunastu miesięcy doświadczyła dyskryminacji ze względu na pochodzenie etniczne, średnio mniej niż jeden na trzech Romów pracuje za wynagrodzeniem (Agencja Praw Podstawowych Unii Europejskiej [FRA], 2009). Rozproszeni po całej Europie (i poza nią) Romowie tworzą własne enklawy, nigdzie nie posiadają autonomicznego terytorium etnicznego i wszędzie pozostają mniejszością. To kształtuje tożsamość romską, która nieustannie jest pod presją jakieś większości. Reakcją obronną dla wielu Romów jest izolacja i względne zamknięcie się na społeczeństwa, w których żyją. Towarzyszące im żebractwo, ubóstwo i bezrobocie potęgują niechęć i rosnące zagrożenie atakami ze strony większości.

\section{GRUPY - ODRĘBNOŚĆ - KRYTERIA}

Grupy różnicują się (rozpoznają jako „swoje” i jako „obce”) z uwagi między innymi na następujące kryteria: (1) nazwa własna, czyli endoetnonim; (2) język; (3) zasady życia (praktyki rutynowe) i (4) miejsce do życia.

\section{Endoetnonim}

Nazwy własne podmiotów zbiorowych mają trzy ważne funkcje.

1. Odzwierciedlają ich przyzwolenie na to, aby same mogły się tak określać. Pociąga to za sobą próby uniformizacji, na przykład decyzję grupy o przyjęciu jednej nazwy wobec niej jako dominującej. 
2. Stanowią miernik akceptacji innych podmiotów zbiorowych dla ich istnienia.

3. Są odbiciem ich sity politycznej.

Nazwa "Francuzi". Chociaż jest derywatem od nazwy Francja, ma germańskie korzenie i oznacza "człowieka wolnego". Utrwalała się przynajmniej od IX wieku na mocy instytucji sprzyjających powstaniu państwa.

N a z w a „R o m o wi e”. W 1971 roku, w ramach Światowego Kongresu Romów, niektóre z owych społeczności przyjęły jako nazwę własną określenie Roma - Romowie. Zaczerpnięto ją z języka romani, wywodzącego się z sanskrytu. Słowo Romowie/Rom oznacza „człowieka, męża” (Gerlich, 2011, s. 159). Ten akt samookreślenia się miał wyłącznie charakter polityczny. Został zainicjowany przez przywódców poszczególnych wspólnot, celem zdystansowania się do powszechnie stosowanej wobec nich nazwy Cyganie, mającej wyłącznie pejoratywne konotacje. Określenie to funkcjonuje także w ujęciu naukowym: socjologiczno-etnicznym, dalekim od wartościowania. W tej perspektywie grupy zasiedlające Europę od X wieku i wywodzące się obszaru Indii Północnych, zachowujące w ich językach cechy świadczące o pokrewieństwie z sanskrytem, tworzą jedność etniczną. Przy czym, nie ma ona decydującego wpływu na ich wspólnotę polityczną.

We Francji funkcjonują grupy zaliczane przez naukowców zarówno do Cyganów, jak i Romów. W pierwszym przypadku są to Gitans, którzy zamieszkują głównie południe Francji, zaś w większości przebywają w Hiszpanii. W drugim mowa o grupie Romów, która definiuje się jako Sinti. Osiedlili się oni głównie na wschodzie Francji, w Alzacji, regionie kulturowo związanym z wpływami niemieckimi, i w regionie paryskim. Tam wobec nich stosuje się (egzo)etnonim Manusze i Jenisze (grupy osiadłe także w Niemczech, Szwajcarii oraz Austrii).

Konstatując, Francuzi od wieków akcentowali w polityce zagranicznej i wewnętrznej swój endoetnonim, związany z istnieniem silnej dynastii Franków, której skutki działalności zasadniczo wpłynęły na losy Europy Zachodniej. Natomiast w odniesieniu do grup cygańskich, romskich we Francji, chociaż istnieje ich wyraźne przyzwolenie na posługiwanie się w stosunku do ich wspólnot nazwą, z którą się świadomie identyfikują ${ }^{1}$, co odkreślają na forum publicznym i w mediach, to problemem pozostaje brak wspólnego określenia. Z tego powodu tracą szansę na uznanie ich za podmioty znaczące w sferze publicznej.

$$
\text { Język }
$$

Jego podstawowa funkcja to komunikacja, zaś szeroki krąg jego użytkowników może gwarantować im mocniejszą pozycję kulturową i polityczną.

J ęzyk francuski. Stanowi historycznie ugruntowany i w dużej mierze, mimo istnienia licznych jego wariantów, ujednolicony systemem komunikacji, posiadający wariant pisany. Posługuje się nim około 274 mln osób na świecie (L'Organisation Internationale de la Francophonie [OIF], 2016, s. 8), co daje mu piątą pozycję, po mandaryńskim, angielskim, hiszpańskim i według szacunków arabskim lub hindi. Stanowił narzędzie politycznej dominacji Francji, zarówno w okresie kolonialnym, jak i postkolonialnym, pozwalając utrzymać jej znaczące wpływy kulturowe. W Unii Europejskiej posługuje się nim około $46 \mathrm{mln}$ ludzi (OIF, 2016, s. 8). Stanowi zarazem gwarant tożsamości narodowej związanej z koncepcją obywatelstwa opartego na świadomości konstytucyjnej.

\section{$\cdots \cdots$}

Opinie te potwierdziła pewna reprezentantka elit romskich w czasie jednego ze spotkań w ramach tygodnia poświęconego Romom we Francji, zorganizowanego przez Dom Bretanii oraz Szkołę Języka Francuskiego UAM w Poznaniu, w kwietniu 2016 roku. 
W przypadku grup cygańsko-romskich dominującym sposobem komunikacji okazują się języki własne tych grup, często określane w potocznym obiegu mianem dialektów. Rozproszenie językowe, mimo faktu, że wspólnoty posługują się także językami narodów, wśród których żyją, nie sprzyja budowaniu jedności. Języki własne mają zatem odczuwalnie słabszą pozycję, wobec języka francuskiego, szczególnie te bez odmiany pisanej. Można się ich nauczyć jedynie poprzez kontakt ze wspólnotami. Rodzina i szerszy krąg znajomych stanowią jedyne instytucje nauczające. Sytuacja taka sprzyja samoczynnie marginalizacji grup.

Niekwestionowana pozycja języka francuskiego, czyniąca z niego narzędzie dominacji politycznej i kulturowej, wynika z dwóch faktów: odmiany pisanej i mówionej umożliwiającej komunikację międzynarodową (zob. np. "Circulaire relative a l'emploi de la langue française dans les relations internationales", 1994), jak również jego naukę niezależnie od kontaktu z osobami francuskojęzycznymi oraz szerokiego kręgu użytkowników, którzy nie są obywatelami Francji. O pozycji języka świadczą też dokumenty rządowe standaryzujące jego użycie, na przykład w relacjach międzynarodowych. W przypadku grup cygańsko-romskich nie tylko nie ma jednego wspólnego dla nich języka, ale wciąż utrzymuje się tendencja do pielęgnowania języków wspólnot lokalnych, co sprzyja ich hermetyczności.

\section{"Zasady życia"}

Jako takie podtrzymują wspólnotę, budują jej granice symboliczne i leżą u podstaw autoidentyfikacji. Szczególna rola przypada im w budowaniu pamięci grupowej, ponieważ ich zinternalizowanie, podobnie jak w przypadku języka, odbywa się na drodze codziennie powtarzanych praktyk rutynowych. Co więcej, w określonych okolicznościach stanowią treści, które grupa poddaje ideologizacji i decyduje się uznać za własną "tradycję”.

Specyfika kultur z obszaru Francji zamyka się w pojęciu regionalizmu. Odnosi się ono do specyficznych różnic w mentalności, coraz częściej podlegających ideologii względnej autonomii, ukształtowanych historycznie w obrębie regionów, współtworzących kulturowo, ale nie politycznie państwo francuskie. Świadomość regionalnej odrębności, zwłaszcza po XVII wieku została jednakże podporządkowana poczuciu bycia obywatelem jednego narodu francuskiego, którego obowiązuje jedno prawodawstwo oraz tak zwany model laicki w sferze publicznej.

U grup romskich i cygańskich trudno doszukać się analogicznej sytuacji, mimo przywilejów związanych z posiadania obywatelstwa Unii Europejskiej. Jednakże nie ten fakt tworzy specyfikę tych wspólnot. Decyduje o niej raczej tradycja określana przez nie jako romanipen. Istnieje wiele praktyk w jej ramach. Do jednej z nich należy zakaz łamania określonego tabu przeważnie związanego z regułą czyste/nieczyste. Sprzeniewierzenie się temu, wiąże się z dotkliwymi sankcjami: od kar cielesnych wykonywanych na nastoletnich dziewczetach, po oddalenie z grupy.

Jednym z ciekawych przykładów zaczerpniętym z życia Gitans (Cossée, 2002), świadczących o różnicach w zwyczajach, regulowanych prawem zwyczajowym, jest utrzymanie u kobiet dziewictwa do czasu zamążpójścia. Wiarygodność panny młodej podlega rytualnemu „testowaniu”, co określa się jako „zdejmowanie/podnoszenie chusty”. Sama czynność owiana jest tajemnicą i nie mają do niej dostępu osoby spoza grupy, a więc i potencjalni badacze. Znana jest jedynie z opowieści. Nie wiadomo zatem, czy w tym rytuale dochodzi do defloracji, czy też jest to tylko symboliczne potwierdzenie nietykalności. Jedna ze starszych kobiet ze wspólnoty dokonuje sprawdzenia, czyniąc to w asyście rodzin pana młodego i panny młodej w dniu ich zaślubin. Kiedy okazuje się, że zasada czystości 
nie została dochowana, ślub jest zerwany, zaś pannę młodą w najlepszym wypadku skazuje się na dozgonne publiczne potępienie. Polega ono na nakazie wiązania chusty pod brodą i przyzwoleniu, aby taką kobietę określać jako kurva, nawet, jeśli kiedyś znajdzie ona męża.

Przykład ten świadczy, że zasady rządzące zawieraniem związków małżeńskich, a także pozycja społeczna kobiety w obyczajowości francuskiej i cygańsko-romskiej, radykalnie różnią się od siebie. Jednakże co znaczące, odmienność ta jest postrzegana przez oba podmioty zbiorowe w kategorii „barbarzyństwa”. Francuzów oburza poniżenie kobiet na tle seksualnym, zaś Gitans drażni brak zasad u kobiet francuskich, co definiują jako "rozwiązłość seksualną".

Dla wspólnot romskich o wiele bardziej brzemiennym w skutki społeczne okazuje się ich tryb życia związany z wędrowaniem. Od wieków budził on kontrowersje wśród prowadzących osiadły tryb życia Francuzów. Przemieszczanie się wspólnot romskich budziło niepokój, gdyż jako takie nie mogły one być kontrolowane przez władze dążące do zcentralizowanej polityki polegającej na znoszeniu głębokich różnic kulturowych u grup etnicznych zamieszkujących kraj. Sytuacja Romów wędrownych - o czym pisaliśmy wcześniej - niejednokrotnie prowadziła do ich prześladowań, prowokowała obraźliwe określenia wobec nich, nawiązujące do prymitywizmu, brudu, tępoty i w efekcie społecznej marginalizacji.

Oficjalnie we Francji rozróżnia się dwie kategorie ludności cygańskiej: Gens du Voyage i Romów (por. m.in. Quémener, 2012, ss. 18-19). Określenie Gens du Voyage odnosi się do koczowniczych obywateli Francji, którzy mają mieszane dziedzictwo francusko-romskie, natomiast Romowie to cudzoziemcy, czyli stosunkowo niedawno przybyli Cyganie głównie z Rumunii i Bułgarii. Pomimo różnic prawnych między Romami i Gens du Voyage obie grupy w obliczu barier edukacyjnych, zatrudnienia, mieszkalnictwa i integracji kulturowej są na marginesie francuskiego społeczeństwa. Żyjący często w swych samochodach i ciężarówkach Gens du Voyage mogą liczyć na większą pomoc ze strony francuskiego państwa, podczas gdy Romowie uznawani są za nielegalnych rezydentów. Nieufność samego państwa wobec nich, a także samych Romów wobec francuskich urzędników państwowych, sprawia, że Romowie nie zwracają się o pomoc, bojąc się aresztowania i deportacji.

\section{Zjednoczona Europa: dyskryminacja jako praktyka rutynowa?}

Praktyki rutynowe znacząco różnicują wszystkie podmioty zbiorowe. W naturalny zatem sposób stanowią obszar największej troski członków, a także obszar wart obrony w obliczu potencjalnego zagrożenia. Często stają się także strategiami przetrwania. Radykalnie odmienne, zwykle z trudem poddają się negocjowaniu i zwykle też mogą stać się pretekstem do dyskryminacji.

W graniczących z Francją Włoszech Romowie stali się podobnym celem politycznej nagonki. Od czasu objęcia rządu przez Silvio Berlusconiego jednym z najpilniejszych zadań stała się walka z uliczną przestępczością. Berlusconi do tej przestępczości zaliczył między innymi żebractwo stosowane przez Romów. Pierwszym miastem walki z żebractwem była Wenecja, gdzie wymierzano za nie wysokie kary pieniężne. W ślad za Wenecją poszły inne miasta Italii, na czele z Rzymem. Rząd, któremu zależało na szybkim przeprowadzeniu akcji przeciw Romom, oddelegował trzy tysiące żołnierzy do wspólnych patroli z policją (Babicki, 2008, s. 5). Włochy, analogicznie jak Francja, rozpoczęły eksmisję Romów z ich tymczasowych osad, twierdząc, że są one zagrożeniem dla bezpieczeństwa i zdrowia publicznego, poza tym naruszają też „uświęconą" w krajach kapitalistycznych 
zasadę prawa własności. Likwidacje obozów Romów przybyłych do Włoch z południowo-wschodniej Europy rozpoczęły się już w 2008 roku, gdy tymczasem francuskie represje nasiliły się dwa lata później. Oba kraje twierdziły, że obozy romskie są źródłem uporczywej przestępczości, prostytucji, nielegalnego handlu i zmuszania dzieci do żebractwa. Eksmisje i zrównywanie z ziemią osad romskich rozpoczęło się na obrzeżach dużych miast, takich jak Neapol, Rzym i Mediolan (Radu, 2011).

Podobnie jak we Francji także we Włoszech polityczna nagonka szła w parze z medialną antyromską histerią:

30 października 2007 roku dwudziestopięcioletni rumuński Cygan w Rzymie zgwałcił, zmasakrował i obrabował wracającą do domu żonę kapitana włoskiej marynarki wojennej. Zmarła dwa dni później w szpitalu. Włoskie media spłynęły krwią, ścigając się w epatowaniu makabrycznymi szczegółami zbrodni i ponurą statystyką: było to już 67. morderstwo, 320. gwałt i 2236. napad rumuńskiego autorstwa we Włoszech w tamtym roku (Kowalczuk, 2010).

O tragedii informowały wszystkie włoskie gazety i programy informacyjne. „Corriere della Sera" napisała, że Rumuni zastąpili Marokańczyków i Albańczyków jako włoski koszmar numer jeden. Różnica polega jednak na tym, że Rumuni są teraz Europejczykami takimi jak my (np. „Włosi będą wydalać Rumunów zagrażających bezpieczeństwu”, 2007).

W odpowiedzi na brutalne morderstwo ksenofobiczna Liga Północna zaproponowała, aby wyrzucić z Włoch wszystkich obcokrajowców, którzy nie mają pracy, zaś neofaszyści z Forza Nuova demonstrowali w Rzymie pod hasłem "Włochy dla Włochów”. Na fali antyromskich wydarzeń gabinet ówczesnego premiera Włoch Romano Prodi zezwolił na wprowadzenie dekretu, na mocy którego prefekci policji mogli podjąć arbitralne decyzje o deportacji obywateli Unii Europejskiej stanowiących zagrożenie dla porządku publicznego. Nikt nie miał wątpliwości, że chodziło o Romów. Kontrowersyjny dekret wszedł w życie zaledwie kilka dni po zabójstwie 47-letniej mieszkanki Rzymu.

Na listach deportacyjnych znaleźli się przede wszystkim obywatele Rumunii romskiego pochodzenia, a wiele miejsc, w których koczowali, zostało zlikwidowanych. Polski dziennikarz i korespondent z Rzymu tak pisał o napotkanych Romach obozujących nad Tybrem w okresie stosowania dekretu deportacyjnego:

[Na ławce w pobliżu Tybru] poznałem „swojego" Cygana. Poprosił o papierosa. Dałem mu trzy ostatnie, żeby mnie nie kusiły $w$ drodze powrotnej. Uśmiechną się, podziękował i zniknął w prowadzących do brzegu rzeki chaszczach. Dwa tygodnie później, kiedy siedziałem na tej samej ławeczce, podszedł do mnie ten sam Cygan próbując oddać trzy papierosy. Przysiadł się i zaczęliśmy rozmawiać. Mówił dobrze po włosku. Powiedział, że przyjechał do Włoch trzy lata temu z żoną i dwójką dzieci. Umówiliśmy się na przyszły tydzień, bo obiecałem mu przywieźć mu trochę niepotrzebnych nam ciuchów. Czekał na mnie na ławeczce. Było zimno, więc zaproponował kawę. Zeszliśmy ścieżką stromą skarpą pośród trzcin i weszliśmy na małą polanę, gdzie stało pięć solidnych chat, a wokół skutery. Dowiedziałem się, że wynajmował to miniosiedle za 200 euro miesięcznie od Rumunów, którzy mieszkali tu wcześniej, ale dostali mieszkanie socjalne. Skąd prąd? Ze słupa. Sąsiad jest elektrykiem. Spytałem, czy myślą wracać do Rumunii. Za nic w świecie: "Tu mamy wszystko, a przede wszystkim święty spokój. Nie otacza nas rumuńska nienawiść. Możemy żyć po swojemu". W legalnym obozie nie chcieli mieszkać, bo tam rządziła cygańska mafia i za wszystko ściągała haracz. Na rozchodne wypiliśmy szklaneczkę wina. Odjechałem przekonany, że widziałem szczęśliwych Cyganów. Wtedy widzieliśmy się po raz ostatni. Tydzień później wyczytałem w dziale miejskim "Corriere della Sera", że u końca trasy rowerowej nad Tybrem zlikwidowano mały obóz Cyganów. Policja znalazła 8 skradzionych skuterów, 10 laptopów, biżuterię, fachowy sprzęt do włamań i aresztowała na miejscu kilku Romów. Mają być deportowani. Popedałowałem sprawdzić. Po osiedlu "mojego" Cygana nie było już śladu (Kowalczuk, 2010). 
Polityka antyimigracyjna Włoch i Francji wycelowana w Romów wywołała sprzeciw i krytykę ONZ, Rady Europy, Komisji Europejskiej i międzynarodowych organizacji broniących praw człowieka. Mimo to także inne państwa Unii Europejskiej uciekły się do tych samych metod. Oburzenie to nie przeszkodziło Niemcom podjąć próby deportacji Cyganów z własnego kraju. Na mocy porozumienia między Berlinem a Prisztiną Niemcy przeprowadzili „akcję repatriacyjną" Romów pochodzących z Kosowa. Niemiecki noblista i pisarz Günter Grass w liście otwartym do ministra spraw wewnętrznych Thomasa Maiziere oskarżył swój kraj o straszliwe naruszanie praw człowieka, nazywając deportacje kosowskich Romów większym skandalem od deportacji francuskich (za: „Niemieckie deportacje Romów to skandal", 2010, s. 4).

Warto przy tej okazji wspomnieć o Polsce. Jedna z najgłośniejszych akcji przeciwko Romom odbyła się w końcu czerwca 1996 roku w Warszawie. Policja i straż miejska zlikwidowały dwa koczowiska po obu stronach mostu Grota-Roweckiego. Akcja trwała od drugiej do czwartej nad ranem. Rumuńskich Cyganów była setka, w pośpiechu musieli oni pakować swoje rzeczy. Kilka tygodni przed akcją władze wszczęły alarm, że przez Cyganów Warszawie grozi epidemia, a w obozowisku szerzą się choroby zakaźne. Plotki mówiły o trupach zakopanych w pobliżu koczowiska. Po akcji trupów nie odnaleziono (Ostałowska, 1996). Po spaleniu i zrównaniu przez buldożery romskich lepianek, Jerzy Ficowski, pisarz i badacz kultury cygańskiej napisał: „Nie zapomnę widoku lalek, które się palą, i wrotek. To było jak deratyzacja, dezynsekcja. To nie była deportacja, lecz łapanka. Nad Wisłą odbył się miejscowy stan wojenny" (cyt. za: Ostałowska, 1996, s. 11). Rok później podobna sytuacja spotkała Romów we Wrocławiu. W ostatnich latach mniejsze obozowiska Romów zostały zlikwidowane między innymi w Krakowie, Trójmieście, Płocku, Elblągu. W marcu 1999 roku dokonana została deportacja osiemdziesięciu Romów rumuńskich z Poznania. Wiosną 2014 roku „problem Romów” znów powrócił: poznańskie władze zmusiły romskich imigrantów do opuszczenia nielegalnie zajętego pustostanu przy ulicy Krauthofera. Oficjalnym powodem deportacji był nakaz wyburzenia budynku grożącego zawaleniem. W ich obronie stanęli działacze Wielkopolskiego Stowarzyszenia Lokatorów i miejscowi anarchiści (Wielkopolskie Stowarzyszenie Lokatorów \& Federacja Anarchistyczna sekcja Poznań, 2015).

\section{KONKLUZJE}

Porównanie dwóch podmiotów zbiorowych „Europy": z jednej strony Francji i innych krajów europejskich, z drugiej Romów wyznacza jedynie trop głębszej analizy według zaproponowanych kryteriów opatrzonych wybranymi przykładami. Mimo uproszczeń, ujęcie generalizujące pozwala jednak spojrzeć na zjawisko dominacji w dwóch wymiarach.

Po pierwsze, w kontekście procesu kumulacji potencjału kulturowego podporządkowanego idei „wspólnoty” i zawłaszczania. Sytuacja wspólnot romskich od wieków kształtuje się W relacji różnicowania, manifestującej się w kategorii "obcego". Jako taka służy podmiotom do zaznaczenia granic ich odrębności, zaś z punktu widzenia obserwatorów jest narzędziem opisu (nie wyjaśniania). Jednocześnie owa relacja przebiega w sytuacji „rozproszenia” i „jednoczenia”. W pierwszym przypadku wciąż dominuje ekskluzywność wyrastająca między innym z reguły czystości/nieczystości w ramach romnipen, w drugim inkluzywność regulowana ideą integracji poprzez język francuski i respektowanie „kultury 
francuskiej". W tym wymiarze ważne jest tworzenie instytucji ułatwiających potencjalną dominację.

Po drugie, w perspektywie brutalizacji wzajemnych relacji. Można tu mówić o patologizacji życia codziennego podmiotu zdominowanego, ale także tego, który dominuje. Kryminogenność, slumsy i strategie żebracze prowokują nie tylko dyskurs ksenofobiczny, ale także praktyki eliminujące podmiot zdominowany z przestrzeni geograficznej. Ten wymiar wskazuje na wykorzystywanie instytucji w celu utwierdzenia dominacji.

\section{BIBLIOGRAFIA}

Abélès, M. (2004). Identity and borders: An anthropological approach to EU institutions. Twenty-First Century Papers: On-Line Working Papers, 2004(4), 1-26.

Agencja Praw Podstawowych Unii Europejskiej (FRA). (2009). EU-MIDIS: Badanie UE na temat mniejszości i dyskryminacji: Sprawozdanie "Kluczowe dane”: Część 1. Romowie. Pobrano 4 czerwca 2017, z http://fra.europa.eu/sites/default/files/fra_uploads/413EU-MIDIS_ROMA_PL.pdf

Ardener, E. (1992). Tożsamość i utożsamianie. W Z. Mach \& A. Paluch (Red.), Sytuacja mniejszościowa i tożsamość (ss. 21-43). Kraków: Wydawnictwo Uniwersytetu Jagiellońskiego.

Aronson, E. (2012). Człowiek istota społeczna (J. Radzicki, Tłum.). Warszawa: Wydawnictwo Naukowe PWN.

Babicki, M. (2008). Żebranie jest prawem człowieka. Romano Atmo, 2008(5(17)), 5.

Barzini, L. (2001). Europejczycy. Warszawa: MUZA.

Chojnacki, R. (2008). Stowo od redaktora naczelnego. Romano Atmo, 2008(5(17)), 3.

Circulaire relative a l'emploi de la langue française dans les relations internationales. (1994). Pobrano 30 kwietnia 2016, z http://circulaire.legifrance.gouv.fr/pdf/2009/04/cir_86.pdf

Corbet, S. (2013, July 23). French lawmaker on defensive over Hitler reference. U.S. News \& World Report. Pobrano 2 czerwca 2017, z http://www.usnews.com/news/ world/articles/2013/07/23/french-lawmaker-on-defensive-over-hitler-reference

Cossée, C. (2002). Familles tsiganes et protection de l'intimité. Ethnologie française, 32(1), 49-59. https://doi.org/10.3917/ethn.021.0049

Cudak, K. (2008). Musimy zacząć podziwiać naszych własnych bohaterów. Romano Atmo, 2008(5(17)), 12-13.

Dainotto, R. M. (2007). Europe (in theory). London: Duke University Press.

Francja: Atak Romów na posterunek żandarmerii. (2010, lipiec 18). Gazeta.pl. Pobrano 5 kwietnia 2016, z http://wiadomosci.gazeta.pl/wiadomosci/1,114873,8151339,Franc ja_Atak_Romow_na_posterunek_zandarmerii.html

Francja: Romowie protestują, zablokowali autostradę A1. (2015, sierpień 29). PolskieRadio. pl. Pobrano 5 kwietnia 2016, z http://www.polskieradio.pl/5/3/Artykul/1495952,FrancjaRomowie-protestuja-zablokowali-autostrade-A1

Gerlich, M. A. (2011). Kwestia romska w Rumunii. W T. Szyszlak (Red.), Kwestia romska w polityce państw Europy Środkowej i Wschodniej (ss. 159-176). Wrocław: Fundacja Integracji Społecznej Prom.

Giddens, A. (2009). Europa w epoce globalnej (M. Klimowicz \& M. Habura, Tłum.). Warszawa: Wydawnictwo Naukowe PWN. 
Giddens, A. (2014). Europa: Burzliwy i potężny kontynent (O. Siara, Tłum.). Warszawa: Wydawnictwo Naukowe PWN.

Hann, C. (2012). Transition, tradition, and nostalgia; Postsocialist transformations in a comparative framework. Collegium Antropologicum, 36(4), 1119-1128.

Kowalczuk, P. (2010). Dwie prawdy o Cyganach: ta romantyczna i ta współczesna. wPolityce.pl. Pobrano 4 czerwca 2017, z http://wpolityce.pl/polityka/105220-dwie-prawdy-ocyganach-ta-romantyczna-i-ta-wspolczesna

L'Organisation Internationale de la Francophonie (OIF). (2016). Rapport OIF. Pobrano 30 kwietnia 2016, z http://www.francophonie.org/Langue-Francaise-2014

Mirga, A., \& Gheorghe, N. (1997). Romowie w XXI wieku: Studium polityczne. Kraków: Universitas.

Niemieckie deportacje Romów to skandal. (2010). Romano Atmo, 2010(6(30)), 4.

Ostałowska, L. (1996, październik 25). Czwarta nad ranem. Gazeta Magazyn, ss. 11-12.

Palmer, R. (2011). Romani exclusion in France: A case study in Ille-et-Vilaine. Pobrano 4 czerwca 2017, z http://lup.lub.lu.se/luur/download?func=downloadFile\&recordOld=2 153238\&fileOld $=2155374$

Paquot, T., \& Augè, M. (2006). Marc Augè w rozmowie przeprowadzonej przez Thierry Paquot. Journal of Urban Ethnology, 8, 6-18.

Quémener, A. (2012). À la découverte des gens du voyage en France. La revue de l'infirmières, 61(180), 18-19.

Radu, C. (2011). Governmentality and the deportation of Eastern European Roma in Italy and France. Inquiries Journal/Student Pulse, 3(4), 1-2. Pobrano 4 czerwca 2017, z http://www.studentpulse.com/articles/513/governmentality-and-the-deportation-ofeastern-european-roma-in-italy-and-france

Walters, W., \& Haahr, J. H. (2011). Rządzenie Europą: Dyskurs, urządzanie i integracja. Warszawa: Wydawnictwo Naukowe PWN.

Wielkopolskie Stowarzyszenie Lokatorów, \& Federacja Anarchistyczna sekcja Poznań. (2015). Mniejszość bez praw. Imigranci romscy w Polsce [Broszura informacyjna]. Pobrano 2 czerwca 2017, z http://www.rozbrat.org/informacje/publikacje/4121-mniejszobez-praw-imigranci-romscy-w-polsce-broszura-informacyjna

Włosi będą wydalać Rumunów „zagrażających bezpieczeństwu”. (2007, listopad 2). Gazeta Wyborcza. Pobrano 4 czerwca 2017, z http://wyborcza.pl/1,75399,4637219.html 